\title{
PROGRAM BIMBINGAN UNTUK MENINGKATKAN MOTIVASI BELAJAR SISWA
}

\author{
SRI MURNI; ISMANIAR \\ STKIP PGRI Bandar Lambung; Universitas Negeri Padang \\ murni_js56@yahoo.co.id; ismaniar.js@gmail.com
}

\begin{abstract}
The present study is aimed at developing effective guidance program for increasing student's learning motivation. The present study applies quantitative research approach with nonequivalent pre-posttest control group quasiexperimental design, and nonrandom-purposive sampling technique. The data were collected using inventory, interview, and documentary study. The study comes up with the main finding that the tested guidance program is proven to be effective for increasing learning motivation students of 11th grade at SMA Kartika XIX-2 Bandung.
\end{abstract}

Keywords: guidance program; learning motivation

\section{PENDAHULUAN}

Dari beberapa pengertian bimbingan dan konseling yang dikemukan para ahli, dapat disimpulkan bimbingan dan konseling adalah suatu proses pemberian bantuan kepada individu secara berkelanjutan dan sistematis yang dilakukan oleh seorang ahli dengan tujuan supaya individu dapat memahami dirinya, lingkungan, dapat mengarahkan diri dan menyesuaikan diri dengan lingkungan untuk mengembangkan potensi dirinya secara optimal. Bloom (Makmum, 2007) menyatakan taraf kematangan dan kesempurnaan IQ seseorang mencapai 92\% nya sejak usia 13 tahun. Tingkat kematangan intelektual pada usia remaja berubah secara signifikan yang ditandai dengan adanya eksplorasi kematangan intelektual. Tahapan ekplorasi kematangan intelektual dapat berkembang melalui pendidikan yang dimanifestasikan dengan luasnya wawasan informasi dan kapasitas berpikir individu. Dengan demikian, masa remaja merupakan masa yang penuh potensi dalam menentukan keberhasilan akademik.
Salah satu perkembangan masa remaja adalah mengembangkan kemampuan intelektual. Perkembangan intelektual yang harus dimiliki remaja yaitu kemampuan menghadapi dan kemampuan menyesuaikan diri terhadap situasi baru secara cepat, tepat dan efektif, memiliki inisiatif yang tinggi dan kemampuan untuk memperoleh atau menggunakan pengetahuan dalam menyelesaikan masalah serta mampu menetapkan tujuan yang ingin dicapai. Kemampuan intelektual tidak akan berkembang apabila siswa tidak memiliki motivasi belajar yang tinggi.

Motivasi merupakan kekuatan, dorongan dan keinginan yang terdapat dalam diri siswa yang menyebabkan siswa bertindak. Keefe dan Jenkins (Zenzen, 2002) menyatakan "motivation, as it relates to students, is very important. Students who have high motivation to achieve generally do well academically. Students with low motivation do not do well academically". Motivasi merupakan faktor penting yang menentukan kemampuan 
akademis siswa. Siswa yang memiliki motivasi yang tinggi akan bagus secara akademis, sementara siswa dengan motivasi yang rendah akan memiliki kemampuan akademis yang rendah.

Berdasarkan wawancara dengan guru pembimbing di SMA Kartika XIX-2 Bandung menunjukkan ada beberapa indikator siswa memiliki motivasi belajar yang rendah, diantaranya; sikap siswa yang asal naik kelas dan asal lulus, siswa kurang bertanggung jawab dalam mengerjakan tugas, siswa memiliki cara belajar yang kurang efektif sehingga tidak mampu menguasai materi pelajaran dengan baik, memiliki sikap apatis dan tidak percaya diri, ragu dalam mengambil keputusan, tidak memahami tujuan dalam setiap tindakannya, kurang disiplin dalam belajar, tidak mengikuti pelajaran yang diberikan guru dan tidak memanfaatkan waktu luang untuk belajar.

Bimbingan dan konseling memiliki peranan yang sangat penting dalam pendidikan dalam mendukung pencapaian proses belajar mengajar dengan memfasilitasi siswa supaya mampu mencapai perkembangannya secara optimal. Bimbingan belajar dapat membantu para siswa dalam menghadapi dan memecahkan masalah-masalah belajar yang meliputi kebiasaan belajar, mengembangkan motivasi belajar, cara belajar yang efektif dan menyelesaikan tugas-tugas (Nurihsan, 2003).

Berdasarkan penjelasan di atas, peneliti ingin mengangkat masalah "program bimbingan untuk meningkatkan motivasi belajar siswa” (Penelitian Kuasi Eksperimen di SMA Kartika XIX-2 Bandung).

\section{METODE PENELITIAN}

Penelitian menggunakan pendekatan kuantitatif, yaitu suatu pendekatan yang memungkinkan dilakukannya pencatatan dan analisis data hasil penelitian. Metode yang digunakan dalam penelitian adalah quasi experiment. Penelitian quasi eksperimen merupakan metode penelitian untuk mencari perlakuan tertentu terhadap yang lain dalam kondisi terkendali dengan pendekatan kuantitatif (Sugiyono, 2008). Rancangan quasi experiment dengan desain nonequivalent pretest and post test control group design, kelompok eksperimen dan kelompok kontrol diseleksi tanpa prosedur acak. Kedua kelompok tersebut sama-sama memperoleh pretes dan postes, akan tetapi kelompok eksperimen saja yang diberikan treatment (Creswell, 2010).

Tingkat Motivasi belajar siswa diukur sebanyak dua kali yaitu sebelum perlakuan (pretest) dan setelah perlakuan (postest). Pretest bertujuan melihat kesetaraan kemampuan awal kedua kelompok. Postest bertujuan melihat bagaimana pengaruh program bimbingan belajar yang diberikan terhadap peningkatan motivasi belajar siswa dan melihat apakah terdapat peningkatan pada motivasi belajar siswa antara kedua kelompok tersebut.

Populasi penelitian adalah seluruh subjek penelitian (Arikunto, 2006). Populasi adalah siswa kelas kelas XI SMA Kartika XIX-2 Bandung.

Pengambilan sampel dalam penelitian menggunakan teknik sampling purposive. Teknik sampling purposive merupakan cara mengambil sampel dari anggota populasi secara penentuan sampel dengan pertimbangan tertentu (Sugiyono, 2010). Pengambilan sampel penelitian adalah semua siswa yang ada di kelas XI-IPS.1 SMA Kartika XIX-2 Bandung. Kelas XI-IPS1 dipilih berdasarkan pertimbangan hasil belajar siswa sangat beragam dan banyak nilai yang dibawah ratarata.

Inventori yang digunakan dalam penelitian adalah Inventori Motivasi Belajar yang diberikan kepada siswa Sekolah Menengah Atas. Inventori Motivasi Belajar dapat mendeskripsikan efektivitas perlakuan yang telah diberikan. Inventori diberikan pada subyek penelitian yang mengalami masalah dalam motivasi belajar pada waktu sebelum (pretest) dan sesudah (posttest) diberikan perlakuan. Inventori diberikan kepada kelompok ekperimen dan kelompok kontrol.

Wawancara dilakukan terhadap guru bimbingan dan konseling untuk mengetahui visi dan misi sekolah SMA Kartika XIX-2 Bandung, program tahunan bimbingan dan konseling terutama dukungan sistem untuk mengetahui dukungan unsur sekolah terhadap kegiatan bimbingan dan konseling, keadaan sosial-ekonomi dan pola asuh orangtua siswa dapat mempengaruhi semangat belajar siswa, 
serta layanan bimbingan yang telah diberikan guru bimbingan dan konseling untuk memotivasi siswa dalam belajar terutama siswa kelas XI.

Dokumentasi yaitu informasi dari bermacam-macam sumber tertulis yang ada pada responden atau tempat dimana responden bertempat tinggal atau melakukan kegiatan sehari-hari (Sukardi, 2004).

Teknik pengumpulan data dalam penelitian adalah studi dokumentasi. Studi dokumentasi dilakukan untuk memperoleh data seperti nilai rapor,data identifikasi masalah yang dialami siswa, data motivasi belajar siswa, dan data nilai akademik.

\section{HASIL PENELITIAN DAN \\ PEMBAHASAN}

Gambaran umum motivasi belajar siswa kelas XI SMA kartika XIX-2 Bandung berdasarkan hasil pengumpulan data yang diperoleh dengan menyebarkan angket kepada siswa yang menjadi responden penelitian. Tabel 1 menyajikan gambaran motivasi belajar siswa secara umum berdasarkan aspek-aspek motivasi belajar, yaitu: mempunyai tanggung jawab pribadi, menetapkan nilai yang ingin dicapai, bekerja kreatif, berusaha mencapai cita-cita, melakukan antisipasi, dan melakukan kegiatan dengan sebaik-baiknya.

\section{Tabel 1}

Gambaran Umum Aspek Motivasi Belajar Siswa Kelas XI SMA Kartika XIX-2 Bandung

\begin{tabular}{|l|c|c|c|}
\hline \multicolumn{1}{|c|}{ Aspek } & Tinggi & Sedang & Rendah \\
\hline $\begin{array}{l}\text { Mempunyai tanggung jawab } \\
\text { pribadi }\end{array}$ & $15,66 \%$ & $68,67 \%$ & $15,66 \%$ \\
\hline $\begin{array}{l}\text { Menetapkan nilai yang ingin } \\
\text { dicapai }\end{array}$ & $43,37 \%$ & $45,78 \%$ & $10,84 \%$ \\
\hline Bekerja Kreatif & $20,48 \%$ & $69,88 \%$ & $9,64 \%$ \\
\hline $\begin{array}{l}\text { Berusaha Mencapai Cita- } \\
\text { cita }\end{array}$ & $16,87 \%$ & $54,22 \%$ & $28,92 \%$ \\
\hline Melakukan Antisipasi & $24,10 \%$ & $62,65 \%$ & $13,25 \%$ \\
\hline $\begin{array}{l}\text { Melakukan Kegiatan } \\
\text { dengan Sebaik-baiknya }\end{array}$ & $26,51 \%$ & $66,27 \%$ & $7,23 \%$ \\
\hline
\end{tabular}

Data pada tabel 1 menunjukkan bahwa setiap aspek motivasi belajar siswa secara umum berada pada kategori sedang, baik di lihat dari aspek mempunyai tanggung jawab pribadi, menetapkan nilai yang ingin dicapai, berkerja kreatif, berusaha mencapai cita-cita, melakukan antisipasi , dan aspek melakukan kegiatan dengan sebaik-baiknya
Pengujian efektivitas pelaksanaan program bimbingan dilakukan dengan menggunakan atau membandingkan selisih pretest dan posttest pada kelompok eksperimen. Pengujian dilakukan dengan menggunakan SPSS 20.0 for Windows.

Tabel 2

Hasil Perhitungan Uji t Selisih Pretest dan Posttest Kelompok Eksperimen Kelas XI SMA Kartika XIX-2 Bandung

\begin{tabular}{|l|l|l|l|l|l|}
\hline Kelompok & Mean & STDV & T. Hitung & Df & Sig \\
\hline Eksperimen & 7,428 & 4,375 & 8,984 & 27 &, 000 \\
\hline Kontrol & 1,500 & 2,501 & 3,173 & 27 &, 004 \\
\hline
\end{tabular}

Berdasarkan hasil uji-t di atas, pada kelas eksperimen diperoleh $\mathrm{t}_{\text {hitung }} 8,984>\mathrm{t}_{\text {tabel }} 1.703$ dengan signifikansi $0,000<0,05$, ini menunjukkan bahwa Ho ditolak, yang berarti terdapat perbedaan atau peningkatan yang signifikan antara nilai pretest dan posttest kelas 
eksperimen setelah diberi perlakuan.

Sedangkan pada kelas kontrol diperoleh $t_{\text {hitung }}$

$3,173>t_{\text {tabel }} 1.703$ dengan signifikansi

$0,000<0,05$. Akan tetapi pada kelas kontrol

tidak diberikan perlakuan yang sama seperti

kelas eksperimen.

Hasil analisis tentang efektivitas program bimbingan menunjukkan intervensi atau perlakuan yang diberikan kepada siswa mempengaruhi peningkatan motivasi belajar siswa, dan terjadi perbedaan yang signifikan antara hasil pretest dengan hasil posttest. Program bimbingan belajar terbukti efektif dalam meningkatkan motivasi belajar siswa kelas XI SMA Kartika XIX-2 Bandung.

Keefektifan program didukung dengan temuan sebagian besar siswa setelah mengikuti program mengalami peningkatan pada aspek tanggung jawab pribadi, menetapkan target belajar yang ingin dicapai, kemampuan untuk bekerja secara kreatif, kemampuan berusaha mencapai apa yang diinginkan, kemampuan untuk mengantisipasi pencapaian pembelajaran dan kemampuan melakukan setiap kegiatan dengan sebaik-baiknya.Peningkatan yang terjadi juga terlihat pada saat peneliti merefleksi kepada siswa yang menanyakan bagaimana perubahan yang terjadi pada diri siswa setelah mengikuti layanan bimbingan. Siswa mengatakan sangat senang mendapatkan layanan bimbingan yang diberikan, merasan adanya perubahan pandangan untuk mencapai prestasi belajar yang tinggi harus memiliki motivasi belajar yang tinggi dan cara belajar yang lebih baik. Siswa akan mengubah cara belajar yang kurang efektif.

Tabel 3

Hasil Uji Paired T-Test Program Bimbingan Untuk Meningkatkan Motivasi Belajar

\begin{tabular}{|l|c|c|c|c|c|c|}
\hline \multicolumn{1}{|c|}{ Aspek } & Mean & $\begin{array}{l}\text { Standar } \\
\text { Deviasi }\end{array}$ & T. Hitung & Df & Signifikan & Keterangan \\
\hline $\begin{array}{l}\text { Mempunyai } \\
\text { tanggung jawab } \\
\text { pribadi }\end{array}$ & 1,28571 & 1,35693 & 5,014 & 27 &, 000 & Signifikan \\
\hline $\begin{array}{l}\text { Menetapkan nilai } \\
\text { yang ingin dicapai }\end{array}$ & 1,28571 & 1,35693 & 5,014 & 27 &, 000 & Signifikan \\
\hline Bekerja kreatif &, 89286 & 1,42307 & 3,320 & 27 &, 003 & Signifikan \\
\hline $\begin{array}{l}\text { Berusaha } \\
\text { mencapai cita-cita }\end{array}$ & 1,28571 & 1,35693 & 5,014 & 27 &, 000 & Signifikan \\
\hline $\begin{array}{l}\text { Melakukan } \\
\text { antisipasi }\end{array}$ & 1,03571 & 1,13797 & 4,816 & 27 &, 000 & Signifikan \\
\hline $\begin{array}{l}\text { Melakukan } \\
\text { kegiatan dengan } \\
\text { sebaik-baiknya }\end{array}$ & 2,28571 & 1,38396 & 8,739 & 27 &, 000 & Signifikan \\
\hline
\end{tabular}

Berdasarkan hasil uji-t di atas, keenam aspek mengalami kenaikan yang signifikan. Dengan kata lain kenaikan aspek-aspek tersebut menunjukkan bimbingan efektif dalam meningkatkan motivasi belajar siswa. Senada dengan perubahan perilaku siswa yang ditunjukkan ketika mengikuti layanan. Pada awalnya siswa lebih suka keluar masuk ketika mengikuti layanan tetapi setelah mengikuti beberapa kali layanan siswa lebih betah untuk duduk di kelas mengikuti layanan. Siswa menunjukkan perubahan pemahaman bahwa belajar dan motivasi belajar sangat penting untuk meningkatkan motivasi belajarnya setelah mengikuti layanan bimbingan.

Selain itu, siswa mengungkapkan sangat senang mengikuti layanan bimbingan. Siswa menjadi bersemangat datang ke sekolah tepat waktu, menggunakan waktu luang untuk mengulang pelajaran dan siswa juga mulai 
aktif bertanya apabila ada materi pelajaran yang tidak dipahami.

Hasil penelitian menunjukkan program bimbingan efektif untuk meningkatkan motivasi belajar siswa kelas XI SMA Kartika XIX-2 Bandung secara umum motivasi siswa mengalami peningkatan.

Motivasi belajar merupakan hal yang sangat penting bagi siswa untuk mewujudkan perilaku yang terarah pada suatu tujuan tertentu dan mampu berusaha memecahkan masalahnya secara efektif dan efisien. Pentingnya motivasi belajar bagi siswa dalam kehidupan sehari-hari baik di lingkungan keluarga maupun di sekolah dapat membangkitkan semangat dan self-competition secara sehat untuk bertindak lebih baik dan mengungkapkan perasaan puas terhadap hasil prestasi yang telah dicapai siswa, membiasakan siswa mendiskusikan pendapat atau cita-cita supaya mampu mencapai tujuan yang diinginkan (Purwanto, 2006).

$\begin{array}{clr}\text { Motivasi } & \text { belajar } & \text { merupakan } \\ \text { kecenderungan } & \text { berprestasi } & \text { dalam }\end{array}$ menyelesaikan aktivitas atau pekerjaan dengan usaha yang aktif sehingga memberikan hasil yang terbaik, motivasi mendorong seseorang untuk mencapai tujuan yang diinginkan. Meningkatkan motivasi belajar siswa mampu menggerakkan siswa dalam melakukan usaha untuk mencapai hasil belajar yang lebih baik.

Motivasi belajar dapat tumbuh dengan dorongan dari dalam diri sendiri maupun dari luar diri. Faktor kebutuhan dapat dijadikan salah satu motivasi yang berasal dari diri sendiri untuk berprestasi.

Meningkatkan kebutuhan terhadap sesuatu untuk mendapatkan prestasi dapat mendorong seseorang untuk meraihnya. Bimbingan belajar mampu meningkatkan motivasi belajar siswa dengan cara memberikan layanan bimbingan sesuai yang dibutuhkan oleh siswa. Cara peningkatan motivasi belajar dapat berupa dorongan yang diberikan kepada siswa supaya menyadari pentingnya belajar dan bagaimana kontribusi motivasi dalam belajar sehingga mampu menumbuhkan rasa ketertarikan siswa dalam belajar.

Siswa yang memiliki motivasi belajar tinggi diyakini memiliki aspirasi pendidikan yang tinggi karena siswa memiliki keyakinan atas kemampuan belajar yang dimiliki. Bantuan untuk meningkatkan keyakinan atas kemampuan belajar diberikan pada siswa dengan motivasi belajar sedang atau rendah. Konselor mendorong siswa untuk berprestasi atau melakukan sesuatu yang terbaik untuk meningkatkan kemampuan belajar.

Pencapaian aspek-aspek motivasi belajar siswa secara umum berada dalam ketegori sedang. Terdapat peningkatan setelah pelaksanaan program bimbingan untuk meningkatkan motivasi belajar siswa kelas XI SMA Kartika XIX-2 Bandung. Pencapaian aspek-aspek motivasi belajar siswa kelas kontrol berada pada kategori sedang. Aspekaspek tersebut diantaranya mempunyai tanggung jawab pribadi, menetapkan nilai yang ingin dicapai, bekerja kreatif, berusaha mencapai cita-cita, melakukan antisipasi dan melakukan setiap kegiatan dengan sebaikbaiknya. Pencapaian aspek-aspek motivasi belajar siswa cukup baik dan perlu adanya bimbingan untuk mengarahkan pada pendekatan yang preventif dan pengembangan, yaitu mengembangkan motivasi belajar siswa di sekolah sehingga siswa mampu berprestasi yang tinggi.

Hasil penelitian menunjukkan pada aspek mempunyai tanggung jawab pribadi sebagian siswa memiliki ketekunan dalam belajar atau memiliki kesungguhan dan tekad dalam mencapai prestasi belajar, bertanggung jawab dengan tugas yang diberikan oleh guru dan siswa mampu memiliki sikap puas dengan pekerjaan sendiri yang berarti menunjukkan pada seberapa jauh siswa menyukai setiap pekerjaan atau tugas. Bertanggung jawab merupakan sikap yang harus dikembangkan pada masa remaja karena remaja akan mengerjakan tugas ataupun pekerjaan dengan sepenuh hati. Melatih remaja untuk memiliki tanggung jawab pribadi berarti memberikan kesempatan untuk mengembangkan diri dengan memberikan kepercayaan, dan memberikan kesempatan kepada remaja untuk berinteraksi lebih luas dengan teman sebayanya.

Siswa yang memiliki motivasi belajar yang baik akan melakukan tugas atau tanggung jawab terhadap pekerjaannya, siswa yang bertangggung jawab terhadap pekerjaannya akan puas dengan hasil belajarnya. Koeswara 
(1995) menjelaskan tanggung jawab pribadi merupakan kesadaran individu akan perilaku atau perbuatannya yang disengaja maupun tidak disengaja. Tanggung jawab berarti seseorang melaksanakan kewajibanterhadap tugas yang dikerjakan.

Berdasarkan hasil penelitian menunjukkan mempunyai tanggung jawab pribadi harus dimiliki oleh setiap siswa dalam mewujudkan motivasi belajar yang optimal. Siswa membutuhkan layanan bimbingan untuk meningkatkan motivasi belajar dalam menumbuhkan ketekunan dalam belajar, memiliki sikap bertanggung jawab dengan tugas yang diberikan oleh guru, dan puas dengan pekerjaan sendiri yang berarti siswa menunjukkan seberapa jauh siswa menyukai pekerjaannya. Upaya layanan bimbingan dilakukan dengan pemberian layanan dasar berupa layanan bimbingan klasikal.

Pada aspek menetapkan nilai ingin dicapai sebagian siswa mampu menetapkan nilai yang ingin dicapai dan mampu berusaha menguasai pelajaran secara tuntas. Siswa perlu lebih meningkatkan kemampuannya untuk melakukan perbaikan tugas-tugas yang diberikan guru untuk mendapatkan nilai tambahan, membaca buku sebelum materi yang disampaikan oleh guru, memanfaatkan waktu luang untuk mengulang pelajaran supaya semua materi pelajaran dikuasai secara tuntas.

Handoko (1992) menjelaskan menetapkan nilai yang harus dicapai atau sesuai standar keunggulan mampu berusaha fokus terhadap hal yang menjadi target pencapaian dan perhatian sepenuhnya terhadap tujuan yang ingin dicapai sehingga mendapat nilai yang diharapkannya. Siswa harus berusaha dengan baik dan penuh semangat untuk mendapatkan prestasi yang optimal.

Siswa harus menguasai materi pelajaran untuk mencapai nilai yang sesuai dengan standar keunggulan. Pencapaian nilai dilakukan supaya siswa mendapatkan prestasi belajar yang optimal di sekolah. Siswa memerlukan layanan bimbingan untuk meningkatkan motivasi belajar siswa dalam menetapkan nilai yang ingin dicapai dan berusaha belajar menguasai materi pelajaran dengan baik dan tuntas.
Siswa mengalami peningkatan setelah diberikan pelayanan bimbingan belajar untuk meningkatkan motivasi belajar siswa pada aspek bekerja kreatif. Siswa mampu menampilkan sesuatu yang bervariasi dalam belajar, mencari alternatif untuk menyelesaikan tugas secara tuntas. Siswa yang memiliki motivasi belajar yang tinggi akan giat untuk mencari cara yang kreatif untuk menuntaskan tugas-tugas sekolah yang diberikan oleh guru. Siswa menggunakan berbagai cara yang efektif dengan caranya sendiri untuk lebih memahami materi yang disampaikan oleh guru ataupun bagaimana memahami materi pelajaran apabila belajar mandiri. Siswa akan lebih mudah menguasai materi pelajaran dan mendapatkan hasil belajar atau prestasi belajar yang tinggi.

Suherman (2007) mengemukakan tiga syarat dalam berpikir kreatif, yaitu kreatif melibatkan respon dan gagasan baru, dapat mengatasi persoalan secara realistis, dan terdapat usaha untuk mempertahankan ide-ide original. Terdapat tiga faktor yang mempengaruhi berfikir kreatif: kemampuan kognitif (termasuk di dalamnya kecerdasan di atas rata-rata, kemampuan melahirkan gagasan baru dan gagasan yang lain; sikap terbuka (seseorang yang kreatif mempersiapkan diri menerima secara terbuka, memilih minat yang beragam dan luas, dan sikap yang bebas, otonom dan percaya kepada diri sendiri.

Berusaha bekerja kreatif dilakukan melalui proses kreatif yang menuntut kecakapan, keterampilan, dan motivasi yang kuat. Kemampuan seseorang untuk berusaha kreatif memiliki tingkat yang berbeda-beda dan memerlukan cara bagaimana mengembangkan kreativitas tersebut. Kemampuan siswa dalam meraih kesuksesan belajar berdasarkan standar nilai yang ingin dicapai tidak terlepas dari usaha dan kreativitas siswa dalam belajar. Prestasi siswa di sekolah menjadi tugas guru pembimbing melalui layanan bimbingan dan konseling untuk mewujudkannya. Keterampilan bekerja kreatif dalam layanan bimbingan dapat meningkatkan motivasi belajar siswa sehingga siswa mampu meningkatkan prestasi belajarnya di sekolah.

Siswa mengalami peningkatan pada aspek berusaha mencapai cita-cita setelah mengikuti layanan bimbingan belajar untuk 
meningkatkan motivasi belajar siswa. Siswa mampu menetapkan cita-cita yang ingin dicapai dan siswa menunjukkan sikap ulet dalam belajar seperti tidak mudah putus asa dan memiliki kemauan yang kuat dalam mencapai tujuan dan cita-cita. Siswa berusaha mencapai cita-cita merupakan berusaha sebaikbaiknya dalam belajar dan memiliki motivasi yang tinggi dalam belajar. Motivasi tinggi dapat ditunjukkan dengan sikap rajin mengerjakan tugas dan mengulang pelajaran di rumah, tekun, ulet dan tidak mengundur-undur waktu belajar. Seseorang berusaha mencapai cita-cita di masa yang akan datang dapat menjadi pedoman dalam memaksimalkan ketercapaian cita-cita, yaitu memahami memiliki masa depan merupakan hal yang sangat penting, membangun motivasi yang kuat, mengenali potensi diri, merencanakan target dimasa depan dan mengevaluasi rencana masa depan (Purwanto, 2006).

Mussen, et al (1984) mengemukakan motivasi belajar seringkali dimanifestasikan dalam bentuk perilaku motivasi berprestasi, seperti tekun dalam mengerjakan tugas yang sulit, bekerja giat untuk mencapai penguasaan, dan memiliki tugas yang menantang tetapi tidak terlalu sulit.

Siswa harus mempunyai cara atau kiat untuk mencapai cita-cita untuk mencapai citacita, seperti menentukan yang menjadi prioritas utama, membuat perencanaan yang matang, memiliki tekad yang kuat, menghargai dan memanfaatkan waktu dengan baik.

Hasil penelitian menunjukkan siswa mengalami peningkatan setelah diberikan layanan bimbingan belajar. Siswa diharapkan dapat meningkatkan kemampuan melalui layanan bimbingan diharapkan untuk mengerjakan tugas yang diberikan oleh guru, kemampuan berusaha keras untuk mencapai cita-cita yang dinginkan.

Siswa mengalami peningkatan pada aspek melakukan antisipasi setelah mengikuti program bimbingan belajar untuk meningkatkan motivasi belajar siswa. Siswa mampu mempersiapkan diri dengan matang untuk belajar dan mempersiapkan semua keperluan untuk belajar. Siswa mampu mengantisipasi apabila menemui kesulitan yang mungkin terjadi dalam belajar. Siswa cenderung tidak mampu untuk menyelesaikan setiap permasalahan yang dihadapinya, tidak mampu menerima resiko yang berat dan cenderung menyalahkan orang lain apabila siswa tidak mempersiapkan diri pada setiap kegagalan yang mungkin terjadi.

Suryabrata (1981) mengemukakan individu mampu menghadapi kegagalan yang dialami secara realistik, mampu melakukan tindakan untuk menanggulangi kegagalan secara realistik. Siswa diharapkan mampu menghadapi sesuatu secara rasional dan realistik. Perilaku yang ditunjukkan untuk mempertahkan diri dari kegagalan pada umumnya kurang disadari, sehingga dapat menimbulkan keadaan semakin kurang efektif.

Siswa mampu melakukan kegiatankegiatannya dengan baik, siswa mampu menghindari kegagalan setelah diberikan layanan bimbingan belajar. Antisipasi yang dilakukan oleh siswa diharapkan dapat mempersiapkan semua keperluan dan peralatan sebelum kegiatan belajar dimulai.

Aspek melakukan setiap kegiatan dengan sebaik-baiknya mengalami peningkatan setelah mengikuti kegiatan layanan bimbingan belajar. Artinya, siswa sudah cukup mampu memperlihatkan sikapsikap positif dalam belajar, seperti; siswa membuat jadwal setiap kegiatannya dan berusaha mematuhinya, siswa sudah menunjukkan ketelitian dalam mengerjakan semua tugas yang diberikan oleh guru, dan siswa mulai memikirkan bagaimana melengkapi buku paket dan alat tulis yang dibutuhkan untuk belajar.

Hasil penelitian mengambarkan bimbingan belajar merupakan layanan bimbingan dan konseling yang sangat penting di sekolah. Bimbingan belajar merupakan bantuan yang diberikan kepada siswa supaya mampu memecahkan kesulitan belajar baik di sekolah maupun di rumah. Bimbingan belajar yang dimaksud dalam penelitian adalah membantu siswa untuk menyesuaikan diri dalam situasi belajar, dapat meningkatkan keterampilan belajar, membiasakan belajar yang berkelanjutan sehingga siswa memiliki tinggi di sekolah.

Kingskey (Bahri, 2002) "learning is the process by which behavior (in the broader sense) is originate or changed through practic or training”. Belajar adalah proses dimana 
perilaku (dalam arti luas) ditimbukan atau diubah melalui praktik atau latihan. Cronbach (Bahri, 2002) berpendapat "learning is shown by change in behavior as a result of experience". Belajar sebagai suatu aktivitas yang ditunjukkan oleh perubahan perilaku sebagai hasil dari pengalaman.

Bimbingan belajar berkaitan dengan permasalahan-permasalahan belajar yang siswa hadapi. Materi bimbingan belajar meliputi pemantapan sikap belajar yang efektif, memahami makna belajar dalam kehidupan sehari-hari dan untuk masa depan, pemantapan disiplin belajar dan selalu berlatih dengan baik belajar mandiri ataupun belajar kelompok. Tugas pembimbing adalah membantu siswa mengatasi permasalahan yang dihadapinya agar sukses dalam belajar dan mampu menyesuaikan diri terhadap semua tuntutan program atau pendidikan.

Program bimbingan dilaksanakan untuk meningkatan motivasi belajar siswa dengan beberapa alasan, materi yang diberikan sesuai dengan kebutuhan siswa, mengejak siswa memahami pentingnya belajar dan bagaimana kontribusi motivasi dalam belajar, mengajak siswa terlibat langsung dalam kegiatan layanan di kelas. Motivasi belajar siswa tidak hanya dilihat dari perubahan tingkah laku dan sikapnya saja, akan tetapi bisa dilihat dari hasil tes akhir yang diberikan kepada siswa setelah mereka mengikuti program bimbingan. Peningkatan yang terjadi bisa dilihat dari bagaimana perbedaan hasil tes awal dan tes akhir setelah diberikan program bimbingan untuk meningkatkan motivasi belajar siswa.

\section{SIMPULAN DAN SARAN}

Simpulan berdasarkan hasil penelitian dan pembahasan yang telah diuraikan pada bagian terdahulu adalah kategori motivasi belajar siswa kelas XI SMA Kartika XIX-2 secara umum berada pada kategori sedang. Hasil penelitian menunjukkan motivasi belajar siswa setelah mengikuti program bimbingan belajar untuk meningkatkan motivasi belajar siswa kelas XI SMA Kartika XIX-2 Bandung secara umum mengalami peningkatan.

Hasil penelitian menunjukkan bahwa: (1) sebagian besar siswa mampu mempunyai tanggung jawab pribadi setelah mengikuti program bimbingan belajar, (2) terdapat peningkatan pada aspek menetapkan nilai yang ingin dicapai setelah mengikuti program bimbingan belajar, (3) sebagian besar siswa mampu bekerja kreatif setelah mengikuti program bimbingan belajar, (4) sebagian besar siswa mampu berusaha mencapai cita-cita setelah mengikuti program bimbingan belajar, (5) siswa mampu melakukan antisipasi setelah mengikuti program bimbingan belajar, dan (6) siswa mampu melakukan setiap kegiatan dengan sebaik-baiknya setelah mengikuti program bimbingan belajar.

Hasil analisis tentang efektivitas program bimbingan belajar menunjukkan intervensi atau perlakuan yang diberikan kepada siswa mempengaruhi peningkatan motivasi belajar siswa, dan terjadi perbedaan yang signifikan antara hasil pretest dengan hasil posttest. Dengan kata lain program bimbingan belajar terbukti efektif dalam meningkatkan motivasi belajar siswa kelas XI SMA Kartika XIX-2 Bandung.

Saran dari hasil penelitian yang dilakukan sebagai berikut:

1. Guru pembimbing hendaknya lebih memperhatikan pemberian motivasi belajar kepada seluruh siswa secara merata pada saat proses pembelajaran sehingga mampu memberikan dorongan positif yang bertujuan untuk meningkatkan prestasi belajar siswa.

2. Siswa hendaknya meningkatkan motivasi dalam belajar sehingga mampu mengembangkan potensi akademik yang dimiliki dengan optimal.

3. Sekolah dapat mengembangkan kualitas pendidikan untuk siswa dan memberikan sumbangan positif terhadap kemajuan sekolah untuk mengembangkan wawasan serta ilmu pengetahuan dalam layanan bimbingan belajar di sekolah terkait dengan motivasi siswa.

4. Bagi peneliti selanjutnya sebagai bahan kajian untuk mengembangkan penelitian lebih lanjut tentang perbaikan kegiatan pemberian layanan untuk meningkatkan mutu kualitas layanan bimbingan yang diberikan. Khususnya dalam penggunaan 
layanan bimbingan belajar untuk meningkatkan motivasi belajar siswa.

\section{DAFTAR PUSTAKA}

Arikunto, S. (2006). Prosedur Penelitian: Suatu Pendekatan Praktik. PT. Rineka Cipta. Jakarta.

Bahri, S. (2002). Strategi Belajar Mengajar. PT Rineka Cipta. Jakarta.

Creswell, J.W. (2010). Reserch Design: Pendekatan Kualitatif, Kuantitatif, dan Mixed. Edisi Ketiga, Pustaka Pelajar. Yogyakarta.

Handoko, M. (1992). Motivasi Daya Penggerak Tingkah Laku. Kanisius. Yogyakarta.

Koeswara, E. (1995). Teori Motivasi dan Penelitiannya. Angkasa. Bandung.

Mussen, et al. (1984). Chlid Development and Personality. Arcan. Jakarta.
Nurihsan, J. (2003). Dasar-dasar Bimbingan dan Konseling. Mutiara. Bandung.

Purwanto, N. (2006). Psikologi Pendidikan. PT. Remaja Rosdakarya. Bandung.

Sukardi, D.K. (2004). Metodologi Penelitian Pendidikan. Bumi Aksara. Yogyakarya.

Suryabrata, S. (1981). Psikologi Balajar. Depdikbud. Jakarta.

Sugiyono. (2010). Metode Penelitian Pendidikan: Pendekatan Kuantitatif, Kualitatif, dan $R \& D$. Alfabeta. Bandung.

Suherman, AS.U. (2007). Manajemen Bimbingan dan Konseling. Madani. Bekasi.

Uno, H.B. (2012). Teori Motivasi dan Pengukurannya: Analisis di Bidang Pendidikan. Bumi Aksara. Jakarta.

Zenzen, T.G. (2002). Achievement Motivation. University of Wisconsin. Stout. 